\title{
TWO NEW SPECIES OF PLANT PARASITIC NEMATODES Hirschmanniella bananae n.sp. (Nematoda: Pratylenchidae) AND Scutellonema tanlamense n.sp. (Nematoda: Hoplolaimidae) ASSOCIATED WITH BANANA IN VIETNAM
}

\author{
Nguyen Ngoc Chau ${ }^{1,2}$ \\ ${ }^{1}$ Graduare University of Science and Technology, VAST \\ ${ }^{2}$ Institute of Ecology and Biological Resources (IEBR), VAST
}

\begin{abstract}
During investigation on the plant parasitic nematodes on bananas in North and Central provinces of Vietnam carried out in 1995 two new species were found, Hirschmanniella bananae n.sp. and Scutellonema tanlamese n.sp. Hirschmanniella bananae n.sp. is characterized by having 6 annuli in lip region, areolation of entire lateral field and presence of a mid-terminal mucro at the tail end. The new species is close to H. shamini Ahmad, 1972 but differs from H. shamini by longer body length in females (1450-1750 $\mu \mathrm{m} v s$ 1190-1360 $\mu \mathrm{m})$, longer stylet longer $(18-20.5 \mu \mathrm{m}$

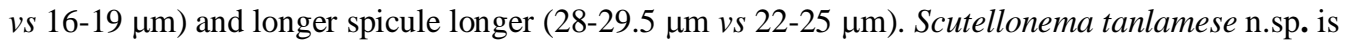
characterized by lip region with three annuli and numerous longitudinal ridges (18) in basal annulus and structure of lateral field at the tail region with inner lines extending to tail terminus. The new species is closest to $S$. brachyurus type B (African populations) described by Van Den Berg et al. in 2013 but can be distinguished by body length shorter $(643-708 \mu \mathrm{m} v s$ 777-820 $\mu \mathrm{m})$, stylet length shorter (24.5-26.5 $\mu \mathrm{m} v s$ 28-29.5 $\mu \mathrm{m})$, and also by structure of lateral field with two inner lines going throught at tail region and vulval edge distinct with epiptygma appearing double and folded into vagina.
\end{abstract}

Keywords: Hirschmanniella, Scutellonema, bananas, North and Central Vietnam, plant parasitic nematodes, new species, taxonomy.

Citation: Nguyen Ngoc Chau, 2017. Two new species of plant parasitic nematodes Hirschmanniella bananae n.sp. (Nematoda: Pratylenchidae) and Scutellonema tanlamense n.sp. (Nematoda: Hoplolaimidae) associated with banana in Vienam. Tap chi Sinh hoc, 39(3): 253-263. DOI: 10.15625/0866-7160/v39n3.10665.

*Corresponding author: nguyengochau.iebr@gmail.com

Received 19 August 2017, accepted 12 September 2017

\section{INTRODUCTION}

Banana (Musa paradisiaca L.) is one of the important fruit crops in Vietnam and is used as desert fruit as well as staple food. Banana is grown everywhere; apart from some state farms, every household at the countryside grows banana. Up to 2014 in total 50,200 ha bananas were planted with about 1,4 million tons of fruit produced. Most of these products is consumed domestically for dessert and food cooking, one fourth of the production is exported to China and Japan.

The preliminary surveys on plant-parasitic nematodes in Vietnam were carried out in North Vietnam during 1977-1978, by joined collaboration of Russian-Vietnamese scientists. Ninety species of plant-parasitic nematodes were recorded, among them 24 species associated with banana (Eroshenko et al., 1985). Another survey to assess the occurrence and potential damage of parasitic nematodes on bananas in Vietnam was carried out in 1995. The latter investigation revealed 53 species of plant-parasitic nematodes associated with bananas in North and Central Vietnam. Some species considered to be most common in distribution and detrimental to bananas were Pratylenchus coffeae, Helicotylenchus multicinctus, $H$. dihystera, Meloidogyne incognita and Rotylenchulus reniformis (Nguyen et al., 1997). Among these plant parasitic nematodes, Hirshmaniella spec. n. and Scutellonema spec. $\mathrm{n}$ were revealed as new species but were not putting scientific named for official publication so far. This paper deals 
with the description of these two new species named as Hirschmanniella bananae n.sp. and Scutellonema tanlamese n.sp.

\section{Materials and Methods}

Survey and sampling. A total of 47 combination samples that included soils and roots associated with planed banana varieties $\mathrm{AAA}$ and $\mathrm{AAB}$ were collected from five localities from Northern and Central Vietnam including: Yen Nghia and $\mathrm{Ba} \mathrm{Vi}$ districts (surround Hanoi city), Tam Thien Mau farming (Ha Bac province), Van Giang district (Hai Hung province) and Tanlam Faming (Quang Tri province). Each combination sample was taken $250 \mathrm{~mL}$ soil and roots within a rhizosphere with facial profile $20 \times 20 \times 20 \mathrm{~cm}$ at base of banana tree (Speijer \& De Waele, 1997).

Nematode extraction. Nematodes from 250 $\mathrm{mL}$ soil samples were extracted by a modified Cobb's sieving-decanting technique (ref?). Firstly, the $250 \mathrm{ml}$ soil sample was transferred into a $5 \mathrm{~L}$ capacity container in 3 liters of water, gently stirred to homogenize the sample in the water, and then poured over a standard sieve (22 $\mathrm{cm}$ diameter) with a mesh size of $0.5 \mathrm{~mm}$ into a second container to remove coarse soil and plant particles. This decantation was repeated about 5-7 times, and then the soil solution is filtered over a standard sieve with mesh size 75 $\mu \mathrm{m}$, so as to collect sediment with nematodes. The latter is rinsed over a small sieve described by Nguyen \& Nguyen (1993). Nematodes were killed in water at $65-70^{\circ} \mathrm{C}$, fixed in TAF and mounted in anhydrous glycerin using the slow method of Hooper \& Evans (1993).

All morphometrics were performed with a camera lucida drawing tube. In the measurement and description of the species, the De Man's formulae (I884) are used. Of these some abbreviated letter used as: $\mathrm{L}=$ total body length in $\mu \mathrm{m}$; $\mathrm{a}=$ body length/maximum body width; $b=$ body length/esophageal length; $b^{\prime}=$ body length/distance from anterior end to posterior end of esophageal glands; $\mathrm{c}=$ body length/anal body width; c' = body length/body width at anus; $\mathrm{V}=$ distance from anterior end to vulva $x$ 100/body length; $T=$ distance from cloacal apeature to anterior of testis $\times 100 /$ body length; $\mathrm{m}=$ length of conus as percentage of total stylet length; $\mathrm{O}=$ distance between stylet base and orifice of dorsal esophageal gland in $\mu \mathrm{m}$. All measurements are presented in micrometers and expressed as the mean \pm standard deviation followed by the range.

SEM photographs. The nematodes used for SEM observation were fixed in a $4 \%$ formaldehyde solution and mounted on slide in dehydrated glycerin following Seinhorst's rapid method (1959). When glycerin embedded nematodes were used for SEM. Specimens were first transferred into a small dish filled with a drop of glycerin. Distilled water is added drop by drop until the nematodes are in pure distilled water. Particles which might adhere to the nematodes are removed by ultrasonic treatment for about $5 \mathrm{~min}$. The nematodes are dehydrated using a gradual series of ethanol concentration of $30 \%, 50 \%, 75 \%$ and $95 \%$. After this initial dehydration which lasts for about 8 hours in total. The specimens are left overnight in $100 \%$ ethanol. The standard critical point drying procedure is applied with $\mathrm{CO}_{2}$ this temperature of $31.1^{\circ} \mathrm{C}$ and the pressure at 72.9 bar. During the transportation the specimens are kept into absolute ethanol. The dried nematodes are individually mounted on standard specimens stubs and sputter-coated with gold. The nematodes are picked by hand one by one and put on the specimen table, so that the head of nematodes lies on the glass rod and can be studied en face. The surface of the specimen table consists of an auto-adhesive conducting aluminum tape stick to the nickel-print (glue). The scanning of nematode specimens were observed and taken photographs with the JSM840 (Eisenback, 1991).

All examined nematode specimens was deposited at the Nematode Collection of the Department of Nematology, Institute Ecology and Biological Resources (IEBR) Vietnam Academy of Science and Technology, 18 Hoang Quoc Viet Road, Cau Giay District, 10000 Hanoi, Vietnam.

\section{Descriptions of new species \\ Hirschmanniella bananae n.sp. (Figs 1 \& 2) Measurements}


Holotype (female). $\mathrm{L}=1600 \mu \mathrm{m} ; \mathrm{a}=67.2$; $\mathrm{b}=12.8 ; \mathrm{c}=17 ; \mathrm{c}^{\prime}=6.8 ; \mathrm{V}(\%)=52.6$; stylet length $=19.1 \mu \mathrm{m} ; \mathrm{m}=50$.

Female paratypes $(\mathrm{n}=17) . \mathrm{L}=1582 \pm 98.7$ (1450-1750) $\mu \mathrm{m}$; body width $23.6 \pm 1$ (22.024.5) $\mu \mathrm{m} ; \quad \mathrm{a}=66.8 \pm 2.4 \quad(64.0-71.0)$; esophageal length $=133.1 \pm 9.5(122.5-144.0)$ $\mu \mathrm{m} ; \mathrm{b}=11.9 \pm 0.8$ (10.5-13.0); tail length $=$ $88.9 \pm 6.0$ (77.5-93.5) $\mu \mathrm{m} ; \mathrm{c}=17.9 \pm 2.4$ (16.0$22.5) ; c^{\prime}=6.7 \pm 0.9(5.5-8.1) ; \mathrm{V}=53.7 \pm 1.6$ (52.5-57.0); stylet length $=19.2 \pm 0.8$ (18.020.5) $\mu \mathrm{m} ; \mathrm{m}=50.0 \pm 0.6(49.0-51.0) ; \mathrm{O}=2.5 \pm$
$0.1(2.2-2.6) \mu \mathrm{m}$.

Male paratypes $(\mathrm{n}=12) . \mathrm{L}=1250 \pm 87.6$ (1150-1400) $\mu \mathrm{m}$; body width $20 \pm 1.4(18-22.5)$ $\mu \mathrm{m} ; \mathrm{a}=62.6 \pm 3$ (57.5-65.5); oesophageal length $=114 \pm 13(93-133) \mu \mathrm{m} ; \mathrm{b}=10.9 \pm 0.7$ (10.3-12.3); tail length $=84 \pm 4.5(77-90) \mu \mathrm{m} ; \mathrm{c}$ $=14.4 \pm 1.0(13.0-15.5) ; c^{\prime}=6.6 \pm 1.0(5.5-$ 8.5); testis length $=34.7 \pm 2.7(30-37.5) \mu \mathrm{m}$; stylet length $=18 \pm 0.4(18-19) \mu \mathrm{m} ; \mathrm{m}=49 \pm 1$ (47-50); $\mathrm{O}=2 \pm 0.5$ (1.5-3) $\mu \mathrm{m}$; spicule length $=28 \pm 0.6(28-29.5) \mu \mathrm{m}$; gubernaculum length $=10 \pm 0.5(10-11) \mu \mathrm{m}$.
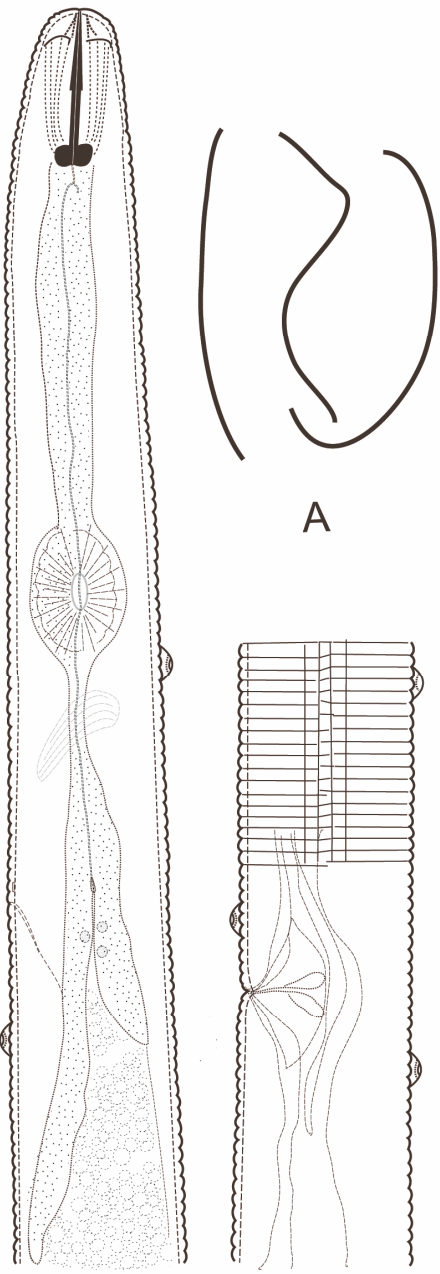

A

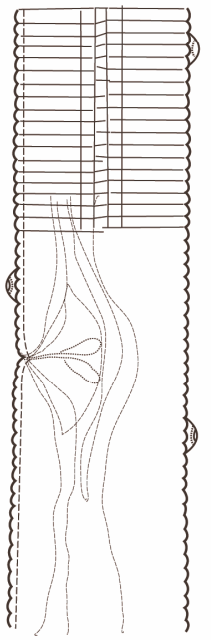

B

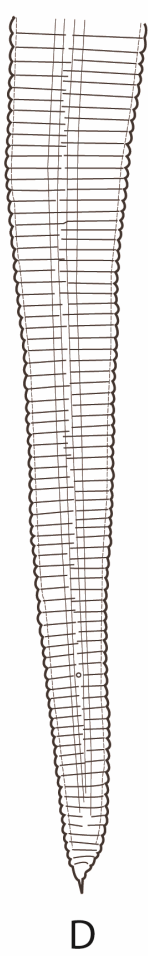

C

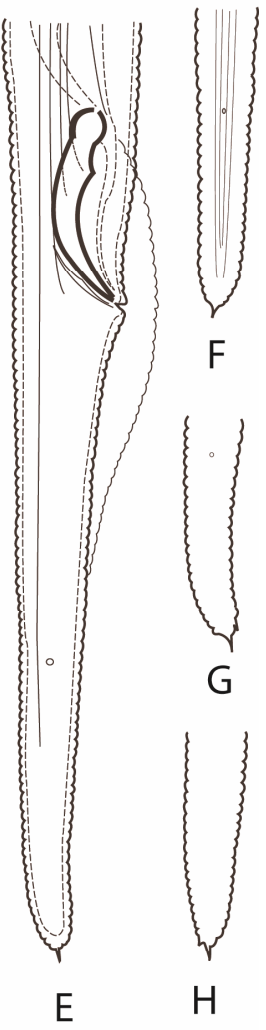

Figure 1. Hirschmanniella bananae $\mathrm{n} . \mathrm{sp}$.

A. Body habitus of heat-relaxed specimens; B. anterior region; C. lateral view at the vulva region with showing infecting of parasitic bacteria (Pasteuria penetrans); D. female tail; E. male tail; F, G, H. variation of the tail terminus. 

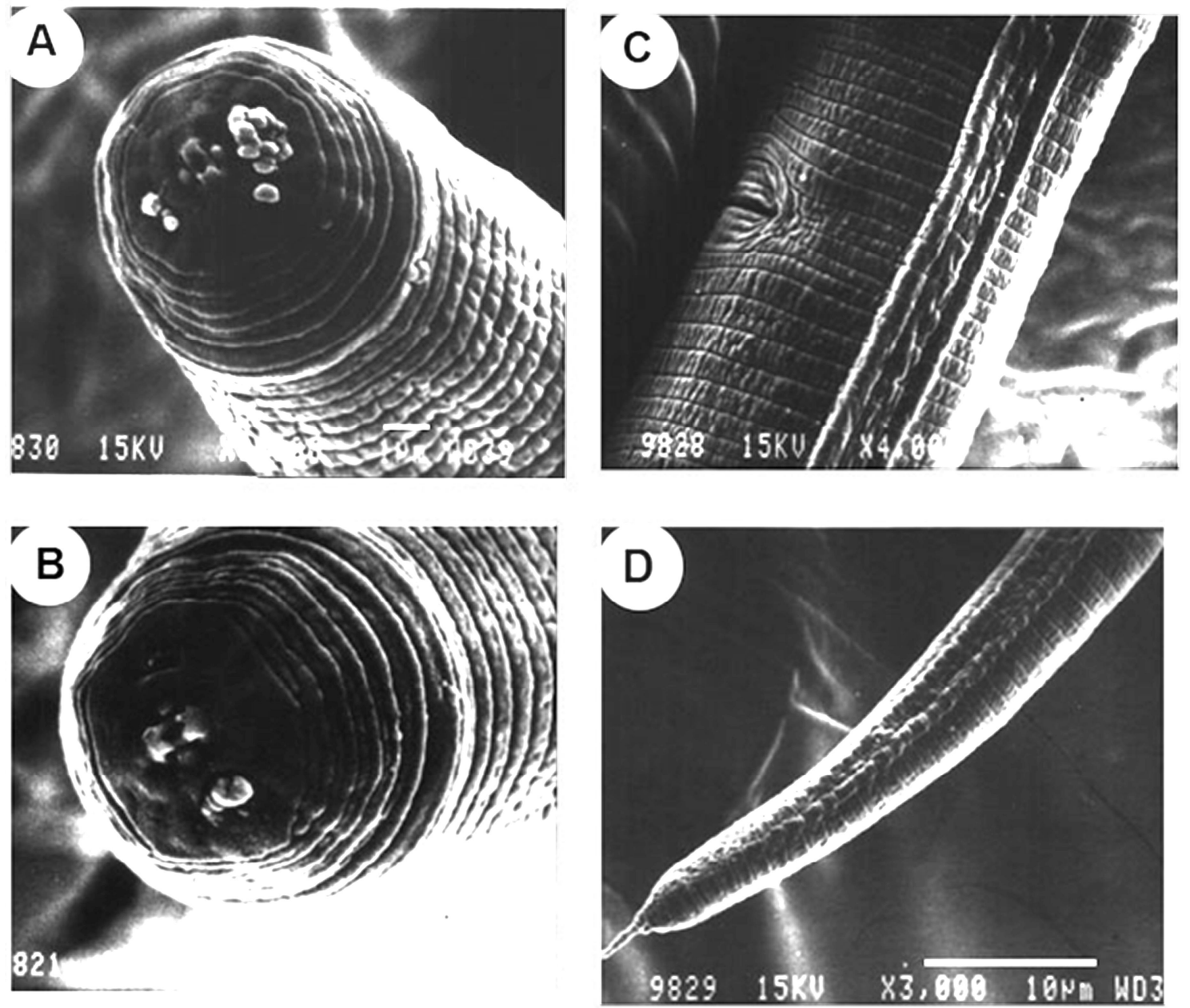

Figure 2. SEM photographs of Hirschmanniella bananae n.sp. A: anterior end in lateral view; B: lip region in en-face view; C: lateral view at vulva showing areolation on entire lateral field; D: tail region. Scale bars are showed on the pictures.

\section{Morphological characterization keep telegraphic style}

Female. Body slender, usually straight, sometimes in irregular curved shape when heath relaxed. Annuli fine, 1.1 -1.2 $\mu \mathrm{m}$ wide at middle body. Areolation present over entirely lateral field that composed of three ridges. Of these two outer ridges crossed by annulation, but inner ridge with irregular annulation (fig. 2C). Lateral field with 4 lines starting from anterior esophageal region and running in parallel up to the mid-tail, where both inner lines join at 6-9 annuli posterior to phasmid, ending at 11-12 annuli from tail end; the outer lines end 4-8 annuli from tail end. At the beginning of lateral field near lip region very indistinct, but apparently starting body diameter posterior to stylet knobs, comprising three bands (i.e., four lines) areolated along entire length of body, more distinct in anterior and posterior region under light microscope whereas SEM photographs showing all three longitudinal bands areolated over entire length of body with anastomoses as twisted lines in middle band (fig. 2 D). Lip region moderately low, rounded and apex flattened, continuous with body contour and composed of five annuli (indistinct in some specimens). SEM photographs showing 
no longitudinal lines on lip annuli; an oblong labial disc, slightly raised above lip region at laterally and fused with labial plate dorsally and ventrally. Amphidial openings forming two slits on lateral sides of labial disc. Cephalic framework moderately sclerotised, extending posteriorly for two or three annuli from basal plate. Stylet short and strong, knobs anteriorly somewhat curved but varying from sloping to anteriorly and posteriorly rounded. Hemizonid distinct, located one to two annuli anterior to the secretory-excretory (SE) pore. SE- pore located 1-2 annuli posterior to level of esophagointestinal junction or at 115-136 $\mu \mathrm{m}$ from anterior end. Esophageal glands are slender and overlapping intestine on ventral side with outstretched point far 171-188 $\mu \mathrm{m}$ from anterior end. Reproductive system didelphicamphidelphic.Ovaries outstretched, spermathecae oval shaped, 9-10 × 13-14 $\mu \mathrm{m}$ in size and filled with plurial sperms, but sometime empty. Vulva at about mid-body to slightly posterior with vulval edge depressed into body contour. Vagina small, straight, and connected with oval vaginal glands. Tail conoid and elongated with terminal mucro. Apart from middle terminal mucro, sometimes a ventral projection present. Phasmids located at 30-31 $\mu \mathrm{m}$ or at 20-21 annuli from tail terminus.

Male. Similar to female in general characters except for sexual differences and smaller body size. Spicules well developed and slightly accurate ventrad. Gubernaculum simple and slightly curved at distal end, not protruding. Tail with 78-84 ventral annuli, straight or slightly curved dorsad with a ventral mucro. Phasmids situated at 35-45 $\mu \mathrm{m}$ and 29-36 annuli to tail tip. In the posterior body four lines of lateral field not joined but expanded and ending at the spicule region.

Bionomics. Both males and female speciments of new species are often infected by parasitic bacteria, Pasteuria penetrans with number from 18 to 36 endospores observed on the body cuticle of each nematode individual. Although in almost banana samples, speciments of $H$. banana often occurs together with speciments of $H$. mucronata, only $H$. bananae is infected with bacteria $P$. penetrans.

Type locality. Specimens of Hirschmanniella bananae n.sp. were collected from banana soils and banana roots Musa paradisiaca L. (AAA group) at Yen Nghia commune, a suburban region of Hanoi city. The new species is also recorded in several other banana regions arounded Hanoi as $\mathrm{Ba} \mathrm{Vi}$ district (Hanoi city). Tam Thien Mau farming of bananas (Ha Bac Province) and banana areas in Van Giang district (Hai Hung Province).

Type specimens. Holotype female, 17 female paratypes and 12 male paratypes are deposited at the Nematode Collection of the Department of Nematology, Institute Ecology and Biological Resources (IEBR), Vietnam Academy of Science and Technology, 18 Hoang Quoc Viet Road, Cau Giay District, 10000 Hanoi, Vietnam.

Differential diagnosis. The new species is readily separated from most species by the areolation of the entire lateral field and presence of a mid-terminal mucro at the tail terminus. In morphology and mophometrics, the new species is similar to H. kwazuna Van Den Berg et al., 2009; H. anchoryzae Ebsary et Anderson, 1982; H. caudacrena Sher, 1968, H. miticausa Bridge, Mortimer et Jacson, 1983 and H. shamini Ahmad, 1972. However, each of these species differs from the new species in the extent of areolation. From $H$. kwazuna the new species differs by a combination characters through a slightly shorter female length at 1450-1750 $\mu \mathrm{m}$ vs $1522-2049 \mu \mathrm{m}$ in females and $1150-1400 \mu \mathrm{m}$ vs 1314-1960 $\mu \mathrm{m}$ in males, shorter esophageal length (distance from anterior end to oesophageal valve) at 122.5-144 $\mu \mathrm{m} v s$ 233-437 $\mu \mathrm{m}$, longer distance from phasmids to tail end at 30-31 $\mu \mathrm{m}$ vs 15-26 $\mu \mathrm{m}$. In addition, the new species does not appeared angular crystal-like inclusions in body cavity and the tail terminus often has a ventral projection. The new species is separated from $H$. areolata by having a shorter stylet in males with 18.5-22 $\mu \mathrm{m}$ vs 25-27 $\mu \mathrm{m}$ and females at 18-20.5 vs 24-27 $\mu \mathrm{m}$; the excretory pore is situated more anteriorly at 66$121 \mu \mathrm{m} v s \quad 121-147 \mu \mathrm{m}$; and the male tail is strongly curved dorsad in most specimens vs 
ventrally arcuate. The new species can be distinguished from $H$. anchoryzae in females are shorter at $1582 \mu \mathrm{m}(1450-1750 \mu \mathrm{m})$ vs 1784 $\mu \mathrm{m}$ (1462-2100 $\mu \mathrm{m})$; stylet longer at 18-20.5 $\mu \mathrm{m} v s$ 16-17 $\mu \mathrm{m}$; and position of the phasmids are more close to the tail terminus at 30-31 $\mu \mathrm{m}$ vs 37-57 $\mu \mathrm{m}$. From $H$. caudacrena and $H$. miticausa the new species differs by having tail terminus with typical mucro and annulation to the end of tail. In size body, the new species might be closest to H. shamini (Ahmad, 1972) which is also commonly appeared in flood rice in Vietnam (Eroshenko et al., 1985) but it differs by longer body length in females at 1450-1750 $\mu \mathrm{m}$ vs $1190-1360 \mu \mathrm{m}$, longer stylet at $18-20.5 \mu \mathrm{m} v s$ 16-19 $\mu \mathrm{m}$ and longer spicule at $28-29.5 \mu \mathrm{m} v s 22-25 \mu \mathrm{m}$.

Etymology. The new species is named after common name of host plant, e.g. banana which the new species are infected.

Scutellonema tanlamense n.sp. (Figs 3 \& 4)

\section{Measurements}

Holotype (female). $\mathrm{L}=620 \mu \mathrm{m} ; \mathrm{a}=28.6 ; \mathrm{b}$ $=7.1 ; b^{\prime}=5.5 ; \mathrm{c}=61.4 ; \mathrm{V}=58.7$; stylet length $=24.5 \mu \mathrm{m} ; \mathrm{O}=23 ; \mathrm{m}=43$.

Female paratypes $(\mathrm{n}=11$ females $) . \mathrm{L}=673$ $\pm 34.6(643-708) \mu \mathrm{m} ; \mathrm{a}=30.3 \pm 1.4$ (28.6$32.4) ; \mathrm{b}=7.9 \pm 0.4(7.1-8.2) ; \mathrm{c}=63.5 \pm 2.3$ (61.2-66.5); V = 57.5 \pm 1.1 (55.0-58.7); stylet length $=25.5 \pm 0.6(24.5-26.5) \mu \mathrm{m} ; \mathrm{O}=23 \pm$ $2.5(20.5-27.5) \mu \mathrm{m} ; \mathrm{m}=43.5 \pm 1.1(42-45)$.

\section{Morphological characterization}

Female. Body usually spiral shaped. Annulation distinct with 1.3-2.0 $\mu \mathrm{m}$ (average $1.7 \mu \mathrm{m})$ wide at middle body. Lip region rounded and mostly not set off, with distinct labial disc rounded and small amphid openings laterally. SEM microphotographs showing clearly three lip annuli and basal annulus arranged with irregular blocks that defined about 18 -20 longitudinal lines over entire annulus. Stylet robust with rounded knobs. Stylet robustus with anterior conical part (as metenchium) usualy shorter than shaft (as telenchium). Lateral fields with four lines in which two outer lines areolated anteriorly opposite to pharyngeal region and posteriorly at the scutellum region. In the SEM photographs areolation in the scutellum region often asymmetric variation posterior to scutellum two inner lines of lateral field continuing till tail end. Tail slightly narrower posteriorly and often dorsally rounded with 9-10 annuli. Median bulb ovoid to moderate rounded, 13-14 $\mu \mathrm{m} \times 14-15$ $\mu \mathrm{m}$ in size. Esophageal glands outstretched, posteriorly with three gland nuclei and overlapping intestine dorsally. Pharyngealintestinal junction distinct and located closely to neve ring. Intestine slightly overlaps rectum. Secretory- excretory pore located opposite to esophageal glands in 8-10 annuli posterior to esophageal intestinal transition valve. Hemizonid two annuli long and situated just anterior to the SE-pore. Scutellum moderate with 3.5-4 $\mu \mathrm{m}$ diameter equivalent two annuli and situated at three annuli posterior to anus and at 6-7 annuli from tail terminus. Reproductive system didelphic-amphidelphic. Vagina straight and connected with two small glands. Two vaginal dilatator muscles distinct but no vaginal constrictor muscles observed. Epiptygma appearing double and folded into vagina. In ventral view, vulva surrounded by oval prominent cuticular border. Ovaries outstretched; spermathecae rounded, with or without sperms.

\section{Male: not found.}

Type locality. A total of 12 specimens of Scutellonema tanlamense n.sp. was extracted from soil around the roots of banana, Musa paradisiaca L. (AAA group) in Tan Lam black paper Farm, Quang Tri province.

Type specimens. Holotype female and 11 female paratypes are deposited at the Nematode Collection of the Department of Nematology, Institute Ecology and Biological Resources (IEBR) Vietnam Academy of Science and Technology, 18 Hoang Quoc Viet Road, Cau Giay District, 10000 Hanoi, Vietnam. 


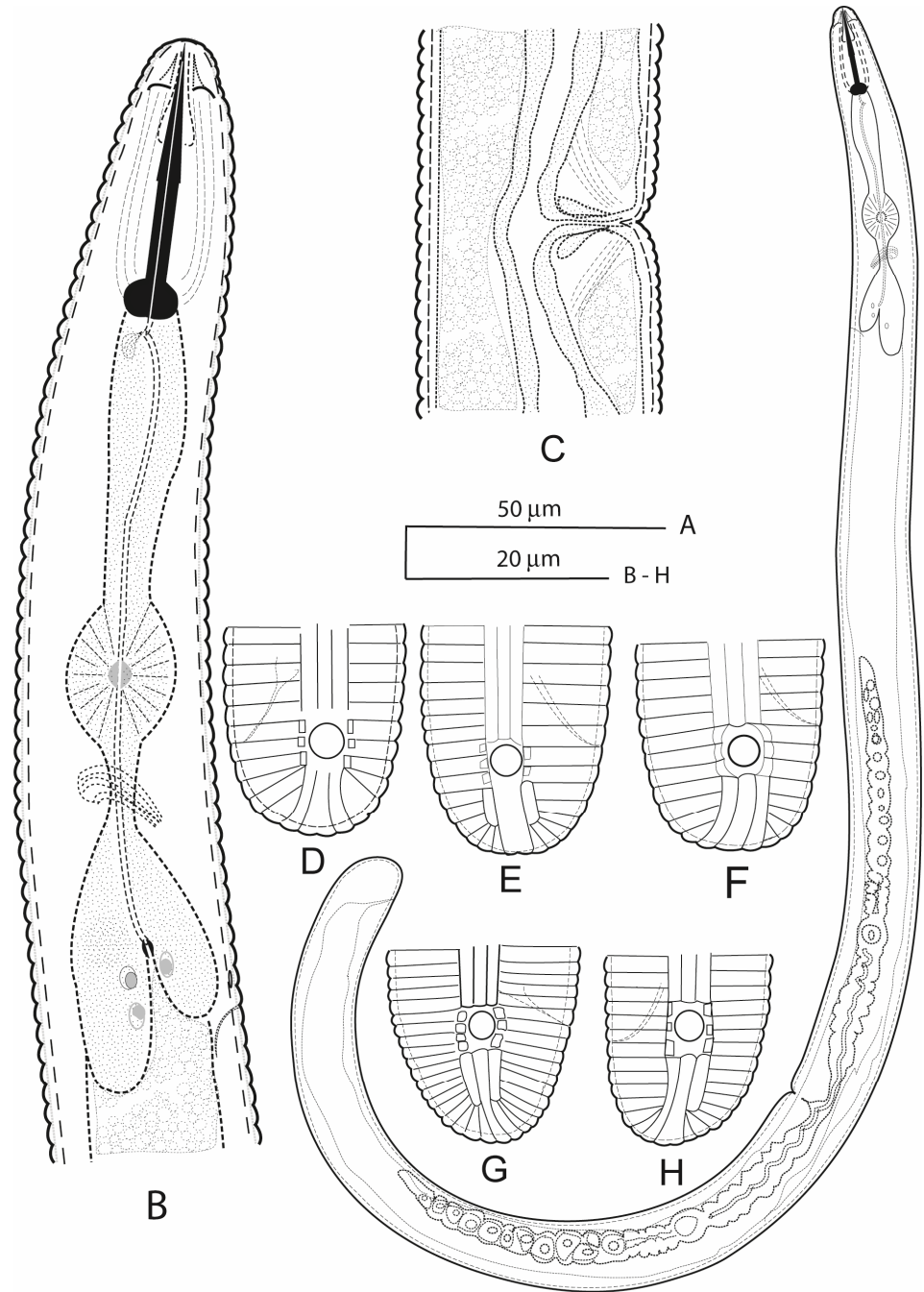

A
Figure 3. Scutellonema tanlamense n.sp. (Female)

A. entire view; B. esophageal region; C. vulva region. $\mathrm{D}, \mathrm{E}, \mathrm{F}$, $\mathrm{G}, \mathrm{H}$. variation of the tail terminus.
Differential diagnosis. In general morphology, the new species is differentiated from all species of the genus by the number of longitudinal ridges in basal annulus with $18-20$ ridges, structure of lateral field at the tail region and inner lines going through out at terminus of the tail. In morphology, the new species come close to S. brachyurus (Steiner, 1938; Eroshenko et Nguyen, 1981) Andrassy, 1958; S. brevistyletum Siddiqi, 1972 and S. vietnamese Eroshenko et Nguyen, 1981. The new species differs from $S$. brachyurus in original description by lip region lower and slightly set off, with 3 annuli vs well set off with 4-6 annuli; more longitudinal ridges on basal annulus i.e. 18 vs 4-12; shorter stylet, 24.5-26.5 $\mu \mathrm{m}$ vs 26-31 $\mu \mathrm{m}$; distinct spermathecae and separation of the inner lines of lateral field at the scutellum region with variation but two inner lines always going through out at terminus of the tail. The new species might be closest to $S$. brachyurus type B described by Van Den Berg et al., 2013 based on three populations collected from South African by a combination characters such as lip region is not set off, with 3 annuli at Scutellonema tanlamense n.sp. vs lip region broadly rounded, well set off with 4 at $S$. brachyurus type B, moreover the new species distinguished to by body length shorter (643$708 \mu \mathrm{m} v s$ 777-820 $\mu \mathrm{m})$, stylet length shorter 
(24.5-26.5 $\mu \mathrm{m}$ vs 28-29.5 $\mu \mathrm{m}$, and also by structure of lateral field with two inner lines going through at tail region and vulval edge distinct with epiptygma appearing double and folded into vagina. In addition, the new species is differentiated from 8 female populations recoded formerly from vegetable crops and coffee in Vietnam by structure of lip region rounded and mostly not set off vs lip region strongly set off, body length shorter (643-708 $\mu \mathrm{m} v s$ 720-780 $\mu \mathrm{m})$, stylet length shorter (24.5$26.5 \mu \mathrm{m} v s$ 28-31 $\mu \mathrm{m}$; vulva position located more anterior with $\mathrm{V}=57.5(55-58.7)$ vs $\mathrm{V}=61$
(57.5-65). Also by structure of lateral field with two inner lines going through at tail region and vulval edge distinct with epiptygma appearing double and folded into vagina. The new species is separated from $S$. brevistyletum in having a longer stylet at 24.5-26.5 $\mu \mathrm{m}$ vs $21-23 \mu \mathrm{m}$; more numerous of longitudinal ridges at basal annulus with 18 vs 10 in $S$. brevistyletum. The new species differs from $S$. vietnamese by shorter length of body at 643-708 $\mu \mathrm{m} v s$ 810$920 \mu \mathrm{m}$ and stylet shorter at 24.5-26.5 $\mu \mathrm{m} v s$ 31-33 $\mu \mathrm{m}$.
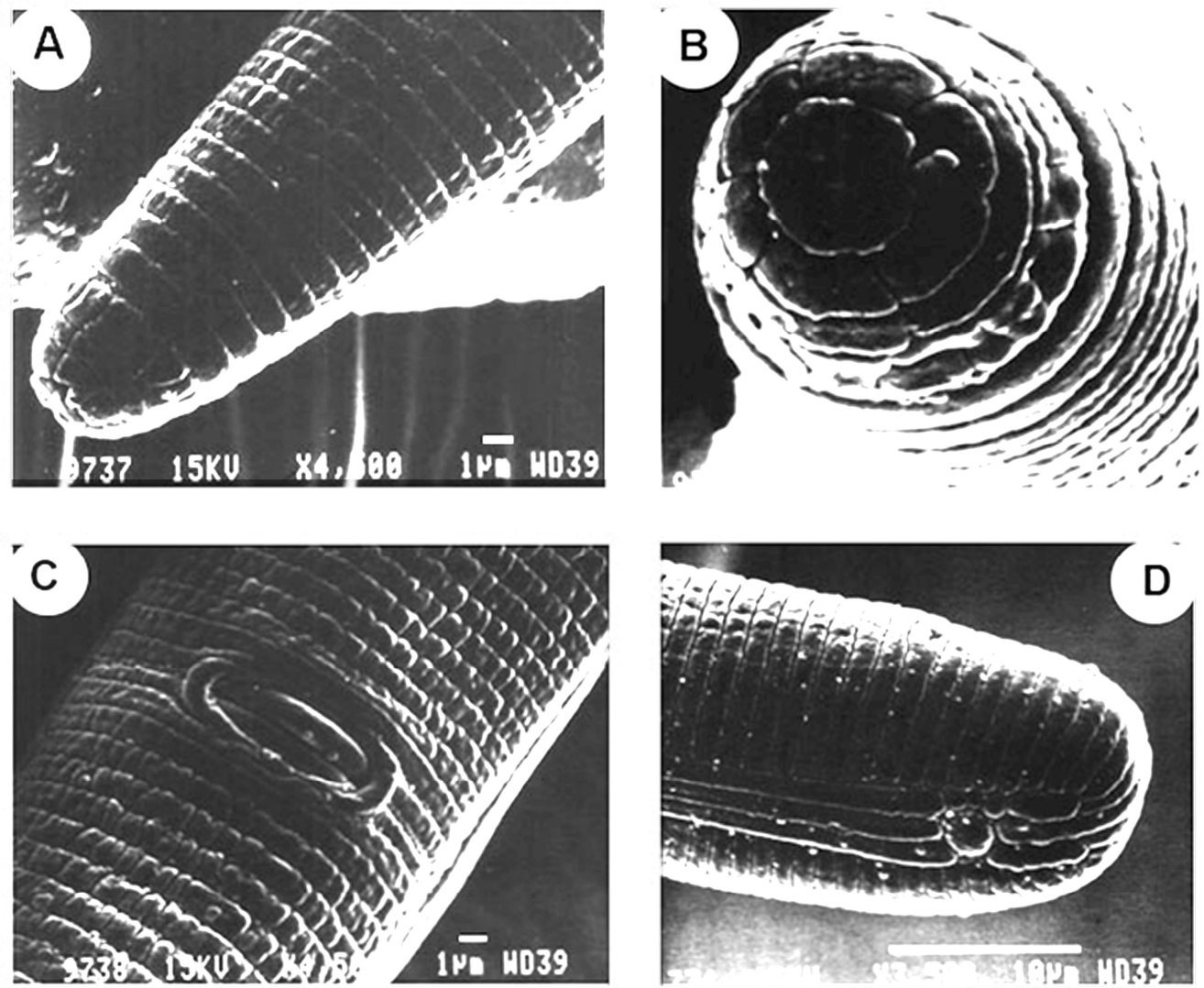

Figure 4. SEM photographs of Scutellonema tanlamense n.sp. (Female) A: anterior region in lateral view; B: lip region en-face view; C: vulva region showing pared epiptigma; D: posterior end showing phasmid and structure of lateral field at tail terminus. Scale bars are showed on the pictures.

Etymology. The species name is derived from the Tan Lam black paper Farm where nematode specimens of new species were found in banana.
Acknowledgements: This work was funded by the Vietnam National Foundation of Science and Technology Development (NAFOSTED) through project 106.12-2012.84. The author 
thanks Prof. Wilfrida Decraemer (UGent) for the editing with valuable suggestions, Miss Rita Van Driessche (UGent) for technical assistance with SEM photographs, Dr. Eric Ragsdale (US Indiana University) for English correction with valuable suggestions.

\section{REFERENCES}

Abdel-Rahman F., Magenti A. R., 1987. Hirschmanniella pomponiensi n.sp. (Nemata: Pratylenchidae), parasitic on bulrush, Scirpus robustus Pursh. Journal of Nematology, 19: 147-151.

Agudelo P., Harshman D., 2011. First report of the spiral nematode Scutellonema brachyurum on lily turf in the United States. Plant Disease, 95(1): 74-74.

Ali S. S., Geraert E., Coomans A., 1973. Some spiral nematodes from Africa. Biologisch Jaarboek Dodonaea, 41: 53-70.

Anderson R. V., 1979. A supplemental key to species of Helicotylenchus Steiner, 1945 (Nematoda: Hoplolaimidae) described since 1972 and a description of $H$. oscepholus n. sp., Canadian Journal of Zoology, 57: 337342.

Andrássy I., 1958. Hoplolaimus tylenchiformis Daday, 1905 (syn. H. coronatus Cobb, 1923) und die Gattungen der Unterfamilie Hoplolaiminae $\quad 1936$. Nematologica, 3: 44-56.

Baujard P., Mounport D., Martiny B, Ndiaye M. A., 1990. Scanning electron microscope observations of two species of the genus Scutellonema Andrássy, 1958 (Nemata: Hoplolaimidae). Revue de Nématologie, 13: 351-360.

Bridge J., Coyne D., Kwoseh C. K., 2005. Nematode parasites of tropical root and tuber crops. In: Luc M., Sikora R. A., Bridge J. (Eds.). Plant Parasitic Nematodes in Subtropical and Tropical Agriculture, 2nd Edition. CABI Publishing, Wallingford, UK, pp 221-258.

Chen D. Y., Chen R. S., Yen J. H., Tsay T. T., Ni H. F., 2006. Species of spiral nematode and lance nematode (Nematoda:
Hoplolaiminae) identified in Taiwan and Kinmen. Plant Pathology Bulletin, 15: 2528.

Chen D. Y., Chen R S., Yen J. H., Tsay T. T., Ni H. F., 2006. Distribution of rice root nematode Hirschmanniella oryzae and a new recorded $H$. mucronata (Nematoda: Pratylenchidae) in Taiwan. Plant Pathology Bulletin, 15: 197-210.

Coyne D. L., Akpheokhai L. I., Adeniran A. F., 2011. The yam nematode (Scutellonema bradys), a potential threat to potato (Solanum tuberosum) production in West Africa. Plant Pathology, 60: 992-997.

De Ley T. I., Mundo-Ocampo M., Yoder M., De Ley P., 2007. Nematodes from vernal pools in the Santa Rosa Plateau Ecological Reserve, California I. Hirschmanniella santarosae n. sp. (Nematoda: Pratylenchidae), a cryptic sibling species of H. pomponiensis Abdel Rahman, Maggenti, 1987. Nematology, 9: 405-429.

Dhanachand C., 2000. Nematodes of medicinal plants in Manipur III: on the species of the genus Scutellonema. Uttar Pradesh Journal of Zoology, 20: 151-158.

Ebsary B. A., Anderson R. V., 1982. Two new species of Hirschmanniella Luc, Goodey, 1963 (Nematoda: Pratylenchidae) with a key to the nominal species. Canadian Journal of Zoology, 60: 530-535.

Eisenback J. D., 1991. Preparation of Nematodes for Scanning Electron Microscopy. In Manual of Agricultural Nematology. Nickle, W.R. (Ed.). Marcel Dekker. Inc. New York Basel-Hong Kong, pp. 87-97.

Eroshenko A. S., Nguyen V. T., 1981. Ectoparasitic nematodes of pineapple plantations in Northern and Central provinces of Vietnam. In: Free Living and Plant Parasitic Nematodes Fauna in Oriental Regions, USSR Academia of Science, Vladivostok, pp. 28-34 (in Russian).

Eroshenko A. S., Nguyen N. C., Nguyen V. T., Doan C., 1985. Plant parasitic nematodes in Northern Vietnam, USSR Academia of 
Science Publishing House, Leningrad, pp. 128 (in Russian).

Fortuner R., 1987. A reappraisal of Tylenchina (Nemata) 8. The family Hoplolaimidae Filipjev, 1934. Revue de Nématologie, 10(2): 219-232.

Fortuner R., Luckk M., 1987. A reappraisal of Tylenchina (Nemata). 6. The family Belonolaiminae Whitehead, 1960. Revue de Nématologie, 10: 183-202.

Fortuner R., 1991. The Hoplolaiminae. In: Manual of Agricultural Nematology. Nickle, W.R. (Ed.). Marcel Dekker. Inc. New York Basel-Hong Kong, pp. 669-720.

Germani G., Baldwin J. G., Bell A. H., Wu X. Y., 1985. Revision of the genus Scutellonema Andrassy, 1958 (Nematoda: Tylenchida). Revue de Nématologie, 8(4): 289-320.

Lal A., 1995. Scutellonema sanwali n.sp. (Nematoda: Hoplolaimidae) from forest of Garhwal Region, India. Afro-Asian Journal of Nematology, 5: 116-118.

Luc M., Goodey J. B., 1964. Hirschmanniella nom. nov. for Hirschmannia. Nematologica, 9: 471 .

Luc M., Goodey J. B., 1962. Hirschmannian n.g. differentiated from Radopholus Thorne, 1949 (Nematoda: Tylenchoidea). Nematologica, 7: 197-202.

Luc M., 1987. A reappraisal of Tylenchida (Nemata). 7. The family Pratylenchidae Thorne, 1949. Revue de Nématologie, 10: 203-218.

Melillo V. A., Troccoli A., 1993. Morphological observation on two Scutellonema species (Nematoda: Hoplolaiminae) from Tanzania. Nematologia Mediterranea, 21: 13-16.

Netscher C., Seinhorst J. W., 1969. Propionic acid better than acetic acid for killing nematodes. Nematologica, 15: 286.

Nguyen C. N., Nguyen V. T., De Waele D., Geraert E., 1997. Plant parasitic nematodes associated with banana in Vietnam.
International Journal of Nematology, 7: 122-126.

Nguyen N. C., Nguyen V. T., 1993. Modified techniques for extraction of plant parasitic nematodes from soils and plant tissues. The Scientific and Technology Achievements Applied to Practice, 1: 41-45.

Nguyen N. C., Nguyen V. T., 2000. Fauna of Vietnam. Volum 4. Plant Parsitic nematodes in Vietnam. Science and Technics Publishing House, Hanoi, pp. 402.

Nguyen N. C., Vu T. T., Trinh P. Q., 2005. Plant parasitic nematodes associated with wild banana in North Vietnam. Problems of Basic Research in Life Science. Science and Technics Publishing House, Hanoi:76-79.

Park S. D., Khan Z., 2007. Occurrence of Scutellonema unum (Nematoda: Hoplolaimidae) on yam (Dioscorea batatas Decne) in Korea. International Journal of Nematology, 17: 91-93.

Ryss A. Y., 1988. Parasitic root nematodes of the family Pratylenchidae (Tylenchida) of the world fauna. Leningrad, USSR, Nauka, pp. 368.

Seinhorst J. W., 1959. A rapid method for the transfer of nematodes from fixative to anhydrous glycerin. Nematologica, 4(1): 6769.

Sher S. A., 1968. Revision of the genus Hirschmanniella Luc, Goodey, 1963 (Nematoda: Tylenchoidea). Nematologica, 14: 243-275.

Sher S. A., 1963. Revision of the Hoplolaiminae (Nematoda) III. Scutellonema Andrassy, 1958. Nematologica, 9(3): 421-443.

Siddiqi M. R., 2000. Tylenchida parasites of plants and insects, 2nd Edition. CABI Publishing, Wallingford, UK, pp. 833.

Sivakumar C. V., Khan E., 1981. Two new species of Scutellonema (Nematoda: Tylenchida) from Tamil Nadu, India. Indian Journal of Nematology, 11(1): 47-52.

Smit J. J., 1971. Deux Nouvelles Especes Africaines D'Hoplolaiminae (Nematoda: T'ylenchoidea): Peltamigratus striatus n. sp. 
et Scutellonema africanum n. sp. Nematologica, 17(1): 113-126.

Speijer P. R., De Waele D., 1997. Screening of Musa germplasm for resistance and tolerance to nematodes. INIBAP technical guidelines. France, CIRAD: pp 42.

Tarjan A. C., 1964. Two new mucronate-tailed spiral nematodes (Helicotylenchus: Hoplolaimidae). Nematologica, 10: 185191.

Van Den Berg E, Coyned T., L. R., Ploeg A. T., Navas-Cortes J. A., Roberts P. A., Yeates G. W., Subbotin S. A., 2013. Morphological and molecular characterisation and diagnostics of some species of Scutellonema Andrássy, $1958 \quad$ (Tylenchida: Hoplolaimidae) with a molecular phylogeny of the genus. Nematology, 15(6): 719-745.
Van den Berg E., Heyns J., 1973. South African Hoplolaiminae. 2. The genus Scutellonema Andrassy, 1958. Phytophylactica, 5(1): 2340.

Van Den Berg E., Subbotin S. A., Handoo Z. A., Tiedt L. R., 2009. Hirschmanniella kwazuna n.sp. from South Africa with notes on a new record of $H$. spinicaudata (Schuurmans Stekhoven, 1944) Luc, Goodey, 1964 (Nematoda: Pratylenchidae) and on the molecular phylogeny of Hirschmanniella Luc, Goodey, 1964. Nematology, 11(4): 523-540.

Zeidan A. B., Geraert E., 1990. Helicotylenchus from Sudan with descriptions of two new species (Nematoda: Tylenchia). Nematologia Mediterranea, 18: 33-45. 